to do justice to this new material he decided to publish a multi-volume opus which would provide the reader with a detailed and more comprehensive picture of political life in Turkey. Unfortunately, his eyes began to trouble him, and despite operations his sight deteriorated rapidly. He was forced to rely more and more on his devoted wife and companion, Melahat Hanim, as well as students and friends to read for him. Research and writing suffered, but at the time of his death three majestic volumes of Türkiye'de Siyasal Partiler (each one almost 700 pages long) had made their appearance in 1984, 1986, and 1989. At the same time, Tarik Hoca's political writings published in the press were collected in 1989 under the title Medeniyetin Bekleme Odass (In the waiting room of civilization).

Tarik Zafer Tunaya has died. But his writings will continue to live on and inspire future generations in Turkey to struggle for the values he fought for all his live: Democracy, tolerance, and the rule of law.

Feroz AhMAD

University of Massachusetts

\title{
MARTIN DICKSON
}

MARTIN DiCKSON slipped away on May 14, 1991, after a long and tenaciously fought battle with heart and kidney disease. Islamic scholarship has lost a qutb; he is now one of the unseen saints.

Martin was born in Brooklyn on March 22, 1924. After graduating from high school, where he distinguished himself as a linguist, he joined the U.S. Army, which identified him as having two aptitudes: driving trucks and learning languages. Martin never got a driver's license, but after induction into the OSS he learned Persian in Michigan, Greek in Egypt and Greece, and Chinese and Russian in China. After the end of the war Martin pursued more formal studies at the University of Washington (B.A. 1948) and Princeton University (Ph.D. 1958), in the course of which he added Arabic and Turkish to his repertoire. During these student years Martin's passion for learning was equaled only by his love of travel and adventure in the new post-war world. His studies in sixteenth-century Central Asian and Iranian history took him to the Sorbonne; to Istanbul, where he was for two years assistant to the man he would always own as his mentor, Zeki Velidi Togan; and to Tehran and Tabriz, where he spent four years and worked for a time as a "local" employee of the Point Four Program. It was this experience, and his desire for it, that helped make Martin such a rarity among his generation of Middle Eastern scholars: He knew intimately, and loved, the languages and cultures that he studied.

Martin spent his entire professional career at Princeton, where he was Professor of Near Eastern Studies at the time of his death. His formal publications were few but, each in its own way, seminal. His dissertation, Shah Tahmasb and the Uzbeks, although unpublished, is still a standard source 
for Safavi historians; a review article of Lockhart's The Fall of the Safavi Dynasty (JAOS 1962) is not only a model of meticulous scholarship and careful criticism, but also a devastating exposé of the ethnicist assumptions that have pervaded orientalism; and collaboration with an art historian and friend, Stuart Cary Welch, produced The Houghton Shahnameh (2 vols., Harvard) in 1981.

Martin published most significantly, however, as a teacher and colleague. The most demanding of mentors and kindest of men, he had a presence that drew the passionate and intellectually ambitious like a magnet. Through his seminars and conversations over dinner or over the telephone, he articulated with great learning a broad and cohesive vision of Muslim societies in the post-Mongol era, a field that was largely terra incognita for most of his contemporaries. The strength of that vision was repeatedly acknowledged by the late Marshall Hodgson in The Venture of Islam. Its depth and breadth is attested by the number of careers, formed or nourished by contact with Martin Dickson, that have been devoted to expressing in detail its inspirational force.

At Martin's funeral service, held in Brooklyn on May 17, 1991, John Livingstone aptly described him as "the sun around whom so many of us revolved." For many of us who came of professional age in the last three decades, whether we were living in a Middle East a shared love of which brought us to him, or pursuing careers in this country, Martin was an anchor and a pole. We still is and, as the ustad-i kamil, will be so for our students.

CoRnell Fleischer Washington University

\section{ILSE LICHTENSTADTER}

ON MAY 23, 1991, Ilse Lichtenstadter (until 1944 Lichtenstädter) died in Boston. Dr. Lichtenstadter was born in Hamburg, Germany on September 10, 1907. She studied at the Universities of Hamburg and Frankfurt-amMain. At the University of Frankfurt she was a student of the Professor of Semitic Philology, Josef Horovitz (1874-1931), an authority on early Islamic historiography, pre-Islamic poetry, and Qur'anic studies. Horovitz's research in these areas inspired that of Dr. Lichtenstadter, commencing with her published doctoral dissertation, "Das Nasīb der altarabischen Qașide," still the standard study of this topic. Horovitz was the son of a renowned orthodox rabbi and made extensive use of his Jewish learning in his studies on the Qur'an. Like other Jewish students of Horovitz, most notably S. D. Goitein, Ilse Lichtenstadter became interested in the relations between Jews and Muslims, on which she published several papers.

Following the award of her doctorate in 1931, Dr. Lichtenstadter received a fellowship from the Notgemeinschaft der Deutschen Wissenschaft. 